\title{
Effect of treatment with adsorbent resin on the volatile profile and physicochemical characteristics of clarified cashew apple juice
}

Adriana Dutra SOUSA ${ }^{1,2}$, Edy Sousa de BRITO ${ }^{1,2 *}$

\begin{abstract}
Increased preference for healthy and functional foods could be an opportunity to increase the consumption of clarified cashew apple juice. Given its level of fructose, glucose, and vitamin C, it can be used as a base in blends. However, its characteristic odor can interfere with the acceptance of these formulations, especially by consumers who are not familiar with cashew aroma. The aim of this study was to evaluate the effect of treatment with macroporous resins (FPA54, FPX66, XAD761, and XAD4) on the volatile profile and physicochemical characteristics of clarified cashew apple juice. After the treatment with the resins, the volatile profile was evaluated using solid-phase microextraction (SPME) and gas chromatography/mass spectrometry (GC/MS). The physicochemical analyses performed were: $\mathrm{pH}$, soluble solids ( $\left.{ }^{\circ} \mathrm{Brix}\right)$, total titrable acidity, reducing sugars, and vitamin C. Gas chromatography analyses showed that XAD4 and FPX66 led to a reduction of the initial amount of volatile compounds to $14.05 \%$ and $15.72 \%$, respectively. These two resins also did not affect the physicochemical characteristics of the clarified cashew apple juice.
\end{abstract}

Keywords: adsorption; Anacardium occidentale; deodorization.

\section{Introduction}

Cashew is a tropical fruit that consists of two parts: the nut and the peduncle. Despite the peduncle potential as a raw material for many products, nearly $90 \%$ of its production is discarded every year. Some reasons that explain such waste are the peduncle high perishability and the cashew nut business importance (OLIVEIRA; ANDRADE, 2011). One of the products obtained by peduncle processing is the clarified cashew apple juice, which has a lower astringency compared to that of non-clarified juice. Clarified juice can be obtained by microfiltration or by a process using gelatin and filtration.

The clarified cashew apple juice can be used to improve nutritional characteristics of mixed drinks by the supplementation of nutrients, such as vitamin $C$ and carotenoids (ASSUNÇÃO; MERCADANTE, 2003; ABREU et al., 2009), sugars (SILVA; RABELO; RODRIGUES, 2012), flavonol glucosides (BRITO et al., 2007; MICHODJEHOUNMESTRES et al., 2009a), anacardic acids (KUBO et al., 2006; TREVISAN et al., 2006) phenolic acids, and prodelphinidins (MICHODJEHOUN-MESTRES et al., 2009b, c). Moreover, some studies show the functional properties of the cashew apple, such as prevention of acute gastritis caused by Helicobacter pylori (KUBO; LEE; KUBO, 1999) and antioxidant activity (ABREU et al., 2009; LUZIA; JORGE, 2011). However, the characteristic intense odor of cashew apple juice can affect blended formulations containing this material.

Cashew apple flavor has been studied specially in the fruit pulp, juice, and condensed water-phase (GARRUTI et al., 2003; CARASEK; PAWLISZYN, 2006; SAMPAIO et al., 2011).
The main odor impact compounds identified were 3-methyl1-butanol, ethyl 3-methyl butanoate, ethyl trans-2-butenoate, ethyl butanoate, 3-methylbutanoic acid, and hexanal. They were responsible for the green, fruity, and cashew-like aroma.

Adsorption can be used for removal of volatile compounds. This technique may be described as an enrichment of compounds, for example, from fluids to the surfaces of solid state bodies. During the accumulation of these compounds interactions between the molecules of the fluid phase (adsorptive) and the solid (adsorbent) occur. The solid surface may be regarded as a site with certain electronic and sterical properties characteristic of the adsorbent matrix structure, which induce energetically heterogeneous energy levels based on the degree of the interaction with the adsorptive (KAMMERER; CARLE; KAMMERER, 2011).

Synthetic resins are polymeric adsorbents with large internal surface areas and a consistent structure. They are manufactured by polycondensation or polymerization (KAMMERER; CARLE; KAMMERER, 2011). Today there are various types of resins, such as the Amberlite series, which have been used for removing apolar, polar, non-aromatic, and aromatic compounds. For example, XAD4 and FPX66 resins consist of a macroreticular crosslinked aromatic polymer and adsorb hydrophobic molecules from polar solvents or volatile organic compounds from vapor streams. XAD761 and FPA54 have a crosslinked phenol-formaldehyde polycondensate matrix. The phenolic hydroxyl and methoxyl groups account for their hydrophilic properties (ROHM..., 2012). The aim of

\footnotetext{
Received 12/13/2012

Accepted 8/4/2013 (005973)

Programa de Pós-graduação em Engenharia Química, Departamento de Engenharia Química, Universidade Federal do Ceará - UFC,

Campus do Pici, Bloco 709, CEP 60455-760, Fortaleza, CE, Brasil

${ }^{2}$ Embrapa Agroindústria Tropical, Rua Dra. Sara Mesquita, 2270, Pici, CEP 60511-110, Fortaleza, CE, Brasil, e-mail: edy.brito@embrapa.br

${ }^{*}$ Corresponding author
} 
this study was to evaluate the effect of treatments with different Amberlite resins (FPA54, FPX66, XAD761, and XAD4) on the volatile profile and the physicochemical characteristics of clarified cashew apple juice to obtain a deodorized juice that can be used as a base product in juice formulations.

\section{Materials and methods}

\subsection{Raw material}

Cashew apples (clone CCP76) collected in Pacajus - CE, Brazil, were used. Five kilograms of fruit were harvested in the second semester of 2010 at the maturity stage 7 (completely ripe) (LOPES et al., 2011). The cashew nuts were removed, and the peduncles were selected followed by washed and sanitized. Pulp was obtained using an expeller type press (INCOMAP, Fortaleza-CE). The juice was clarified using a microfiltration unit, as described by Castro, Abreu and Carioca (2007).

\subsection{Resin treatment}

For resin activation, four chromatographic columns were filled with Amberlite resin types FPA54, FPX66, XAD761, and XAD4. After that $50 \mathrm{~mL}$ of distilled water $\left(60^{\circ} \mathrm{C}\right)$ were added every 15 minutes for three hours. Juice treatment with these resins was performed by transferring $100 \mathrm{~mL}$ to an erlenmeyer flask and keeping it in contact with $20 \mathrm{~g}$ of resin under agitation in a rotatory shaker at $30{ }^{\circ} \mathrm{C}$ and $150 \mathrm{rpm}$ for 1 hour. In addition, an erlenmeyer flask containing only the juice was used as control. Finally, the juice was separated from the resins by filtration using an $8 \mu \mathrm{m}$ pore filter. After treatment, the resins were washed several times with a $\mathrm{NaOH} 2 \%$ solution for regeneration until obtaining a clear solution. Next, it was washed with water to begin the activation process. All juice treatments were performed in triplicate.

\subsection{Isolation of volatile compounds by solid-phase microextraction (SPME)}

Cashew apple juice (10 g) with $\mathrm{NaCl} 30 \% \mathrm{w} / \mathrm{w}$ was kept in a hermetically sealed extraction vial for 45 minutes at $45^{\circ} \mathrm{C}$ under continuous stirring to equilibrate the headspace. Subsequently, the SPME device was inserted into the sealed vial through the septum, and the CAR-PDMS $(85 \mu \mathrm{m})$ fiber was exposed to the sample headspace for 30 minutes for adsorption of volatiles. Following the sampling procedure, the fiber was immediately inserted into the GC injector, and the fiber was thermally desorbed for 3 minutes at $250{ }^{\circ} \mathrm{C}$. Before each sampling procedure, the fiber was automatically conditioned for 5 minutes in the Needle Heater port at $250^{\circ} \mathrm{C}$. This conditioning procedure was enough to guarantee no peaks in blank runs, and it was a good compromise between the chromatography runs and the extraction procedures.

\subsection{Gas chromatography analysis}

Volatile compounds were separated in a CP-Sil-8CB (Varian, Walnut Creek, CA, USA) fused silica capillary column (30 m length, $0.25 \mathrm{~mm}$ id, $0.25 \mu \mathrm{m}$ film thickness) in a Varian model 3800 gas chromatograph. The splitless mode injector was maintained at $250{ }^{\circ} \mathrm{C}$ and the flame ionization detector (FID) at $250^{\circ} \mathrm{C}$. Hydrogen was used as the carrier gas at a flow rate of $1.5 \mathrm{~mL} \mathrm{~min}^{-1}$. The oven temperature was set at $30^{\circ} \mathrm{C}$, kept for 7 minutes, programmed to $90{ }^{\circ} \mathrm{C}\left(3^{\circ} \mathrm{C} \mathrm{min}-1\right)$, and then to $200{ }^{\circ} \mathrm{C}\left(10^{\circ} \mathrm{C} \mathrm{min}^{-1}\right)$, and kept at $200^{\circ} \mathrm{C}$ for 10 minutes.

\subsection{Gas chromatography/mass spectrometry and compound identification}

The volatile compounds were identified using a Shimadzu gas chromatograph (Kyoto, Japan) coupled to a mass spectrometer (GC/MS-QP-2010) at an MS ionization voltage of $70 \mathrm{eV}$ and $1 \mathrm{scan} \mathrm{s}^{-1} \mathrm{MS}$ scan range. Column and oven conditions were the same as those used for the chromatographic analysis. Helium was used as the carrier gas at a flow rate of $1.0 \mathrm{~mL} \mathrm{~min}^{-1}$.

Identification was made by comparing the experimentally obtained mass spectra of the compound with those in the NIST 27 and NIST 147 libraries, comparing the volatile retention index obtained using the CP-Sil-8CB column with the retention indices published in the literature for columns with the same polarity (LINSTROM; MALLARD, 2010), and comparing the volatile mass spectra with the mass spectra of pure compounds analyzed in the same gas chromatograph - mass spectrometer using the same methodological conditions.

\subsection{Determination of volatile compound percentages}

The volatile profile of control sample was used as a reference for comparison with those of the volatiles of the treated juices. The total area of volatile compounds present in the control juice corresponded to $100 \%$, and the percentages of the areas of the volatile compounds of the treated juices were calculated using Equation 1.

$\%$ compound $=\frac{\text { compound area }}{\text { control total area }} \times 100$

\subsection{Physicochemical analysis}

The physicochemical analyses were performed in triplicate for all treatments. The following analyses were performed: $\mathrm{pH}$, determined by direct reading in a WTW potentiometer (model 330i/SET) (ASSOCIATION..., 1999); soluble solids $\left({ }^{\circ} \mathrm{Brix}\right)$, determined by refractometry using an ATAGO refractometer, according to IAL (INSTITUTO..., 2005); total acidity, determined by titration, carried out as described by IAL (INSTITUTO..., 2005) and expressed as g citric acid/100 g; reducing sugars, determined according to Miller (1959); and vitamin $\mathrm{C}$, determined by the colorimetric method (2,6-dichlorophenolindophenol) described by Pearson (1975) and expressed as $\mathrm{mg}$ ascorbic acid/100 $\mathrm{mL}$.

\subsection{Statistical analysis}

The physicochemical results were evaluated using analysis of variance (ANOVA), and the means were compared by the Tukey's test at 5\% significance level. Statistical analysis was performed using the SAS System (STATISTICAL..., 2001) for Windows. 


\section{Results and discussion}

The volatile composition of clarified cashew apple juice is shown in Table 1. A total of 26 compounds were detected by high-resolution gas chromatography and 18 were identified in the control. The volatile compounds were predominantly esters ( $72 \%$ of total identified compounds), followed by aldehydes (16\%) and alcohols (11\%). These results are consistent with those found by Bicalho et al. (2000) and Garruti et al. (2003), who detected many ethyl and methyl esters in Brazilian cashew apples. They found a large number of compounds compared to those of the current study; however, their techniques were different than the ones used here. The authors used organic solvents to eluate the extracted volatiles and injected this mixture into the GC. In the present study, the volatiles were adsorbed onto a fiber that was inserted into the GC injector without solvent. Carasek and Pawliszyn (2006) also found a small number of compounds (14 identified compounds) using SPME with the same fiber used in the present study for the industrialized cashew pulp from the northeastern region of Brazil. The main compounds found in the current study were ethyl 3-methyl butanoate (35.20\%), ethanol (12.02\%), ethyl acetate (11.90\%), ethyl 2-methyl-2-butenoate (7.52\%), ethyl butanoate (6.13\%), ethyl trans-2-butenoate (4.61\%), and ethyl 2-methylbutanoate (4.46\%). Ethanol was the exception when compared to those previous studies since it was found in large amounts. This might be explained by previous sample fermentation since this compound was present in the control and treated juices. Garruti et al. (2003) also found ethyl 3-methyl butanoate as the most abundant compound and others such as ethyl butanoate, methyl 3-methyl butanoate, hexanal, and 3-methyl-1-butanol, which were also found in this study.

The XAD4 resin proved more efficient in removing volatiles if compared to others, reducing the initial amount of volatile compounds (control) to $14.05 \%$. This adsorbent removed the compounds with a positive impact on the odor of the cashew apple juice (cashew odor) and also with a negative impact (offflavors), which leads to a weaker fruity aroma (Kranz, Adler and Kunz (2011) also observed a flavor loss during adsorptive debittering of grapefruit juice using XAD-7HP resin. Although FPX66 resin removed most of the compoounds $(15.72 \%$ of the control), some odor active volatiles such as ethyl propanoate and ethyl 3-methyl butanoate were still present, which imparted

Table 1. Volatile profile and compounds odor quality of clarified cashew juice treated with different resins.

\begin{tabular}{|c|c|c|c|c|c|c|c|c|}
\hline Peak No & Compound & $\begin{array}{l}\text { Retention } \\
\text { Index }\end{array}$ & $\begin{array}{c}\text { Control } \\
(\%)\end{array}$ & $\mathrm{XAD} 4(\%)^{\mathrm{a}}$ & $\begin{array}{c}\text { XAD761 } \\
(\%)\end{array}$ & FPX66 (\%) & FPA54 (\%) & Odor quality ${ }^{b}$ \\
\hline \multicolumn{9}{|l|}{ Aldehyde } \\
\hline 1 & acetaldehyde $^{\mathrm{d}}$ & $<800$ & 1.16 & 1.04 & 0.91 & 0.71 & 0.33 & \\
\hline 23 & benzaldehyde ${ }^{c}$ & 960 & 0.38 & nd & $\mathrm{Nd}$ & nd & nd & Plastic, green, fruity, cashew \\
\hline \multicolumn{9}{|l|}{ Alcohol } \\
\hline \multicolumn{9}{|l|}{ Ester } \\
\hline 3 & ethyl acetate ${ }^{c}$ & $<800$ & 11.90 & 0.33 & 4.53 & 0.32 & 12.11 & Dried cashew, wet cloth, solvent \\
\hline 6 & ethyl propanoate ${ }^{c}$ & $<800$ & 1.39 & nd & 0.37 & 0.68 & 0.52 & Sweet \\
\hline 9 & $\begin{array}{l}\text { methyl 3-methyl } \\
\text { butanoate }^{\mathrm{c}}\end{array}$ & $<800$ & 0.26 & nd & nd & nd & nd & Cashew, sweet, plastic, stinky \\
\hline 13 & $\begin{array}{c}\text { ethyl } \\
\text { 2-methylbutanoate }\end{array}$ & 861 & 4.46 & nd & 0.65 & nd & 1.75 & Cashew, sweet, floral, fruity, apple \\
\hline 14 & $\begin{array}{l}\text { ethyl 3-methyl } \\
\text { butanoate }\end{array}$ & 866 & 35.20 & nd & nd & 0.37 & 14.25 & Cashew, sweet, fruity, ripe fruit \\
\hline 17 & isoamyl acetate ${ }^{\mathrm{d}}$ & 880 & 2.81 & nd & nd & nd & 1.97 & Plastic, unpleasant, solvent, green \\
\hline 20 & ethyl pentanoate ${ }^{c}$ & 906 & 1.28 & nd & nd & nd & 0.36 & Green, herbal, grassy, floral \\
\hline 21 & methyl hexanoate ${ }^{c}$ & 932 & 0.35 & nd & nd & nd & nd & Cashew, sweet, eucalyptus \\
\hline 22 & $\begin{array}{l}\text { ethyl 2-methyl-2- } \\
\text { butenoate }^{\mathrm{d}}\end{array}$ & 948 & 7.52 & nd & nd & nd & 2.01 & $\begin{array}{c}\text { Cashew, sweet, fruity, minty, } \\
\text { pineapple } \\
\text { Cake }\end{array}$ \\
\hline 24 & $\begin{array}{l}\text { ethyl 3-methyl } \\
\text { pentanoate }\end{array}$ & 966 & 0.35 & nd & nd & nd & nd & Cashew, sour, unpleasant \\
\hline
\end{tabular}

${ }^{\mathrm{a}}$ Relative to control; ${ }^{\mathrm{b}}$ Garruti et al. (2003); ${ }^{\mathrm{C}}$ Compound positively identified (pure standard); ${ }^{\mathrm{d} C o m p o u n d ~ i d e n t i f i e d ~ b y ~ M S ~ a n d ~ l i n e a r ~ r e t e n t i o n ~ i n d e x ; ~ n d, ~ c o m p o u n d ~ n o t ~ d e t e c t e d ; ~}{ }^{\mathrm{e}}$ total percentage of not identified compounds. 
Table 2. Physicochemical characterization of clarified cashew apple juice treated with resins.

\begin{tabular}{cccccc}
\hline Treatment & $\begin{array}{c}\text { Vitamin C } \\
(\mathrm{mg} \mathrm{AA} / 100 \mathrm{~mL})\end{array}$ & $\begin{array}{c}\text { SST } \\
\left({ }^{\mathrm{ob}}\right)\end{array}$ & $\begin{array}{c}\text { reducing sugars } \\
(\%)\end{array}$ & $\mathrm{pH}$ & $\begin{array}{c}\text { acidity } \\
(\mathrm{g} / 100 \mathrm{~g})\end{array}$ \\
\hline Control & $159.42 \pm 0.16^{\mathrm{a}}$ & $11.3 \pm 0.2^{\mathrm{a}}$ & $10.45 \pm 0.02^{\mathrm{a}}$ & $4.21 \pm 0.02^{\mathrm{b}}$ & $0.28 \pm 0.01^{\mathrm{a}}$ \\
FPA5 & $117.28 \pm 0.20^{\mathrm{d}}$ & $10.4 \pm 0.1^{\mathrm{b}}$ & $9.58 \pm 0.06^{\mathrm{b}}$ & $5.08 \pm 0.07^{\mathrm{a}}$ & $0.23 \pm 0.02^{\mathrm{b}}$ \\
FPX66 & $134.08 \pm 0.20^{\mathrm{b}}$ & $10.1 \pm 0.3^{\mathrm{b}}$ & $9.56 \pm 0.06^{\mathrm{b}}$ & $4.24 \pm 0.06^{\mathrm{b}}$ & $0.26 \pm 0.01^{\mathrm{ab}}$ \\
XAD4 & $132.85 \pm 0.18^{\mathrm{c}}$ & $10.2 \pm 0.1^{\mathrm{b}}$ & $9.49 \pm 0.03^{\mathrm{b}}$ & $4.23 \pm 0.10^{\mathrm{b}}$ & $0.26 \pm 0.01^{\mathrm{ab}}$ \\
XAD761 & $105.69 \pm 0.06^{\mathrm{e}}$ & $10.3 \pm 0.4^{\mathrm{b}}$ & $9.55 \pm 0.01^{\mathrm{b}}$ & $5.04 \pm 0.07^{\mathrm{a}}$ & $0.23 \pm 0.01^{\mathrm{b}}$ \\
\hline
\end{tabular}

${ }^{\star}$ Means followed by the same letter within the same column do not differ significantly by Tukey test ( $\left.\mathrm{p}>0.05\right)$. Data are expressed as mean \pm standard deviation ( $\mathrm{n}=3$ ).

moderate odor intensities (GARRUTI et al., 2003). The XAD 761 resin reduced the volatiles, but its efficiency was lower (28.80\% of the control). The worst result was obtained using FPA54, which maintained most volatiles in the juice, $51.70 \%$ of their initial value, including those with negative attributes. The resins that obtained better results (XAD4 and FPX66) have an aromatic structure, with affinity for hydrophobic molecules. On the other hand, XAD761 and FPA54 resins have affinity for hydrophilic molecules.

According to the physicochemical analyses (Table 2), there was a vitamin $\mathrm{C}$ decrease in all resin treatments. The concentration reduced from $159 \mathrm{mg} \mathrm{AA} / 100 \mathrm{~mL}$ (control) to 134 (FPX66), 132 (XAD4), 117 (FPA54), and 105 mg AA/100 $\mathrm{mL}$ (XAD761). Despite this decrease, the samples treated with the XAD4 and FPX66 resins showed values close to those of the control, showing better retention of vitamin C. This compound provides health benefits and must be preserved after resin treatment. Resin treatments compared to the control reduced the soluble solids and reducing sugars significantly. There was no difference in the $\mathrm{pH}$ values between the XAD4 and FPX66 and that of the control, while XAD761 and FPA54 showed higher values. This behavior was consistent with the acidity value results, which decreased in relation to the control, and XAD761 and FPA54 showed higher affinity than XAD4 and FPX66. Like volatile compounds, XAD761 and FPA54 have affinity for hydrophilic molecules. Cianci et al. (2005), studying clarified cashew apple juice by microfiltration, found results similar to those of the control for vitamin $\mathrm{C}$, soluble solids, and $\mathrm{pH}$. The higher $\mathrm{pH}$ values obtained using XAD761 and FPA54 may be a consequence of the reduced levels of ascorbic acid, also reflected in acidity determination. Vivekanand, Ajlouni and Iyer (2003) used an adsorbent resin and a weak ion exchanger to improve clarified pear juice quality. These authors also found a decrease in the titratable acidity and increase in $\mathrm{pH}$, without great loss of sugars and other nutritional constituents (minerals and ascorbic acid) in treated juices, but the volatile profile was not evaluated in their study.

\section{Conclusions}

The volatile profile analysis showed that the best resins for deodorization of cashew apple juice were XAD4 and FPX66 due to almost complete volatiles removal and lower effects on the physicochemical characteristics. After resin treatment, juices can be used as an ingredient in the production of blended beverages, especially those involving cashew apple juice.

\section{Acknowledgments}

The authors are grateful for the financial support provided by EMBRAPA, INCT-Frutos Tropicais and CNPq.

\section{References}

ABREU, C. R. A. et al. Bioactive compounds and antioxidant activity of cashew apple (Anacardium occidentale L.) from commercial early dwarf clones. Acta Horticulturae, v. 841, p. 451-454, 2009.

ASSOCIATION OF OFFICIAL ANALYTICAL CHEMISTS - AOAC. Official Methods of Analysis of the Association of Analytical Chemistry. 15th ed. Washington: AOAC, 1999. 2 v.

ASSUNÇÃO, R. B.; MERCADANTE, A. Z. Carotenoids and ascorbic acid composition from commercial pro\#ducts of cashew apple (Anacardium occidentale L.). Journal of Food Composition and Analysis, v. 16, p. 647-657, 2003. http://dx.doi.org/10.1016/S08891575(03)00098-X

BICALHO, B. et al. Application of high-temperature gas chromatography- mass spectrometry to the investigation of glycosidically bound components related to cashew apple (Anacardium occidentale L. var. nanum) volatiles. Journal of Agricultural and Food Chemistry, v. 48, n. 4, p. 1167-1174, 2000. http://dx.doi.org/10.1021/jf9909252

BRITO, E. S. et al. Determination of the flavonoid components of cashew apple (Anacardium occidentale) by LC-DAD-ESI/MS. Food Chemistry, v. 105, p. 1112-1118, 2007. http://dx.doi.org/10.1016/j. foodchem.2007.02.009

CARASEK, E.; PAWLISZYN, J. Screening of tropical fruit volatile compounds using solid-phase microextraction (SPME) fibers and internally cooled SPME fiber. Journal of Agricultural and Food Chemistry, v. 54, p. 8688-8696, 2006.

CASTRO, T. R.; ABREU, F. A. P.; CARIOCA, J. O. B. Obtenção de suco clarificado de caju (Anacardium occidentali, L) utilizando processos de separação por membranas. Revista Ciência Agronômica, v. 38, n. 2, p. 164-168, 2007.

CIANCI, F. C. et al. Clarificação e concentração de suco de caju por processos com membranas. Ciência e Tecnologia de Alimentos, v. 25 , n. 3 , p. $579-583,2005$. http://dx.doi.org/10.1590/S010120612005000300030

GARRUTI, D. S. et al. Evaluation of volatile flavour compounds from cashew apple (Anacardium occidentale L) juice by the Osme gas chromatography/olfactometry technique. Journal of the Science of Food and Agriculture, v. 83, p. 1455-1462, 2003. http://dx.doi. org/10.1002/jsfa. 1560

INSTITUTO ADOLFO LUTZ - IAL. Normas analíticas do Instituto Adolfo Lutz: métodos físicos e químicos para a análise de alimentos. 3. ed. São Paulo: IAL, 2005. 
KAMMERER, J.; CARLE, R.; KAMMERER, D. R. Adsorption and Ion Exchange: Basic Principles and Their Application in Food Processing. Journal of Agricultural and Food Chemistry, v. 59, n. 1, p. 22-42, 2011. http://dx.doi.org/10.1021/jf1032203

KRANZ, P.; ADLER, P.; KUNZ, B. Sorption of citrus flavour compounds on XAD-7HP resin during the debittering of grapefruit juice. International Journal of Food Science and Technology, v. 46, n. 1, p. 30-36, 2011. http://dx.doi.org/10.1111/j.1365-2621.2010.02442.x

KUBO, J.; LEE, J. R.; KUBO, I. Anti-Helicobacter pylori agents from the cashew apple. Journal of Agricultural and Food Chemistry, v. 47, n. 2, p. 533-537, 1999. http://dx.doi.org/10.1021/jf9808980

KUBO, I. et al. Antioxidant activity of anacardic acids. Food Chemistry, v. 99, n. 3, p. 555-562, 2006. http://dx.doi.org/10.1016/j. foodchem.2005.08.023

LINSTROM, P. J.; MALLARD, W. G. (Eds.). NIST Chemistry WebBook. Gaithersburg: National Institute of Standards and Technology. (NIST Standard Reference Database Number, n. 69). Disponível em: <http://webbook.nist.gov>. Acesso em: 20 set. 2010.

LOPES, M. M. A. et al. Caracterização física de pedúnculos de clones de cajueiro anão precoce em diferentes estádios de maturação. Revista Ciência Agronômica, v. 42, n. 4, p. 914-920, 2011. http:// dx.doi.org/10.1590/S1806-66902011000400013

LUZIA, D. M. M.; JORGE, N. Study of antioxidant activity of nonconventional Brazilian fruits. Journal of Food Science and Technology, 2011. http://dx.doi.org/10.1007/s13197-011-0603-x

MICHODJEHOUN-MESTRES, L. et al. Monomeric phenols of cashew apple (Anacardium occidentale L.). Food Chemistry, v. 112, n. 4, 851-857, 2009a. http://dx.doi.org/10.1016/j.foodchem.2008.06.056

MICHODJEHOUN-MESTRES, L. et al. Isolation, Characterization, and Determination of 1-O-trans-Cinnamoyl- $\beta$-D-glucopyranose in the Epidermis and Flesh of Developing Cashew Apple (Anacardium occidentale L.) and Four of Its Genotypes. Journal of Agricultural and Food Chemistry, v. 57, p. 1377-1382, 2009b. http://dx.doi. org/10.1021/jf803174c

MICHODJEHOUN-MESTRES, L. et al. Characterization of highly polymerized from skin and flesh of four cashew apple (Anacardium occidentale L.) genotypes. Food Chemistry, v. 114, n. 3, p. 989-995, 2009c. http://dx.doi.org/10.1016/j.foodchem.2008.10.052

MILLER, G. L. Use of dinitrosalicylic acid reagent for determination of reducing sugars. Analytical Chemistry, v. 31, n. 3, p. 426-428, 1959. http://dx.doi.org/10.1021/ac60147a030

OLIVEIRA, V. H. D.; ANDRADE, A. P. S. Produção integrada de caju. Abrindo portas para qualidade. Disponível em: $<$ http://www.cnpat. embrapa.br/pif/artigol.pdf >. Acesso em 5 nov. 2011.

PEARSON, D. Laboratory Techniques in Food Analysis. London: Cox \& Pearson, 1975.

ROHM AND HASS COMPANY. Product Information. Disponível em: <www.rohmhaas.com>. Acesso em 28 mar. 2012.

SAMPAIO, K. L. et al. Aroma volatiles recovered in the water phase of cashew apple (Anacardium occidentale L.) juice during concentration. Journal of the Science of Food and Agriculture, v. 91, p. 1801-1809, 2011. http://dx.doi.org/10.1002/jsfa.4385

SILVA, I. M.; RABELO, M. C.; RODRIGUES, S. Cashew juice containing prebiotic oligosaccharides. Journal of Food Science and Technology, 2012. http://dx.doi.org/10.1007/s13197-012-0689-9

STATISTICAL ANALYSIS SYSTEM - SAS. SAS User's Guide: Statistics. version 5. Cary: SAS Institute, 2001.

TREVISAN, M. T. S. et al. Characterization of alkyl phenols in cashew (Anacardium occidentale) products and assay of their antioxidant capacity. Food and Chemical Toxicology, v. 44, n. 2, p. 188-197, 2006. http://dx.doi.org/10.1016/j.fct.2005.06.012

VIVEKANAND; AJLOUNI, S.; IYER, M. Quality enhancement of UFclarified pear juice using adsorbent and weak-base resins at different temperatures. Journal of Food Science, v. 68, n. 1, p. 333-338, 2003. http://dx.doi.org/10.1111/j.1365-2621.2003.tb14161.x 